\title{
Ricciopsis sandaolingensis sp. nov., a new fossil bryophyte from the Middle Jurassic Xishanyao Formation in the Turpan-Hami Basin, Xinjiang, Northwest China
}

\author{
Ruiyun Li, Xiaoqiang Li, Hongshan Wang, and Bainian Sun
}

\begin{abstract}
The liverwort family Ricciaceae has a very sparse fossil record in contrast to its large number of living species and its wide distribution. Fossil thalli collected from the Middle Jurassic Xishanyao Formation at the Sandaoling coal mine, Xinjiang, Northwest China are described. Based on detailed comparison of the gross morphology with related fossil and extant species, we assign these thalli to the fossil genus Ricciopsis and establish a new species Ricciopsis sandaolingensis sp. nov. (Ricciaceae). The new fossil species is characterized by its circular-shaped and rosette-forming thallus, dichotomous branching, linear segments, prominent median ridge and entire margins. Ricciopsis sandaolingenesis probably lived on wet or damp soil close to bodies of water, in the shade of ginkgoalean trees in warm and humid climatic conditions. This discovery represents the first fossil record of Marchantiopsida from the Middle Jurassic Xishanyao Formation in the Turpan-Hami Basin, Xinjiang, Northwest China.
\end{abstract}

Ruiyun Li. State Key Laboratory of Continental Dynamics, Shaanxi Key Laboratory of Early Life and Environments (Northwest University), Northwest University Museum, Xi'an, 710069, China.

liruiyun@nwu.edu.cn

Xiaoqiang Li. Shaanxi Institute of Geological Survey, Xi'an, 710054, China. lixq_07@|zu.cn

Hongshan Wang. Florida Museum of Natural History, University of Florida, Gainesville, FL 32611-7800,

USA. hwang@flmnh.ufl.edu

Bainian Sun. School of Earth Sciences, Lanzhou University, Lanzhou, 730000, China. bnsun@lzu.edu.cn

Keywords: new species; Ricciaceae; liverwort; Middle Jurassic; Xishanyao Formation; China

Submission: 17 August 2018. Acceptance: 1 June 2019.

\footnotetext{
Li, Ruiyun, Li, Xiaoqiang, Wang, Hongshan, and Sun, Bainian. 2019. Ricciopsis sandaolingensis sp. nov., a new fossil bryophyte from the Middle Jurassic Xishanyao Formation in the Turpan-Hami Basin, Xinjiang, Northwest China. Palaeontologia Electronica 22.2.42A 1-11. https://doi.org/10.26879/917

palaeo-electronica.org/content/2019/2624-fossil-liverwort-from-china

Copyright: July 2019 Paleontological Society.

This is an open access article distributed under the terms of Attribution-NonCommercial-ShareAlike 4.0 International (CC BY-NC-SA 4.0), which permits users to copy and redistribute the material in any medium or format, provided it is not used for commercial purposes and the original author and source are credited, with indications if any changes are made.

creativecommons.org/licenses/by-nc-sa/4.0/
} 


\section{INTRODUCTION}

Ricciaceae, with thalloid gametophytes and highly reduced sporophytes, is a widespread family of the Marchantiales (Hoffman and Stockey, 1997; Wu et al., 2013). This family includes two extant genera, Riccia L. and Ricciocarpos Corda, and one fossil genus Ricciopsis Lundblad. Depending on the resources to which one refers, the number of accepted species of the genus Riccia varies. For example, The Plant List (http://www.theplantlist.org; Accessed 7 June 2018) includes 176 accepted species while Söderström et al. (2016) lists 152 accepted species. Ricciocarpos is monotypic, with only one species Ricciocarpos natans (Linn.) Corda (Crandal-Stotler and Stotler, 2000). The fossil genus Ricciopsis includes more or less circular-shaped and rosette-forming sterile fossil thalli showing closer resemblance to the Ricciineae than any other living group (Lundblad, 1954).

Liverworts are delicate in texture (Hemanta Singh and Kishor, 2009). Their thalli possess neither lignified wood nor thick cutinized epidermis (Lacey, 1969; Frahm and Newton, 2005; Devos and Vanderpooten, 2009; Moisan et al., 2012; Glime, 2013). Based on the fossil records of bryophytes and observations and experimental data on extant bryophytes, Tomescu et al. (2018) pointed out that bryophytes have preservation potential as good as that of vascular plants. Some inclusions in amber and permineralized bryophytes in carbonate concretions are preserved with exquisite microstructures (e.g., Shelton et al., 2015, 2016; Bippus et al., 2017; Heinrichs et al., 2017; Mamontov et al., 2018; Savoretti et al., 2018). However, compared with the vascular plants, the bryophytes have a rather sparse fossil record (Jordan, 2006; Li et al., 2016b; Tomescu, 2016; Tomescu et al., 2018).

Ricciaceae has very few fossil records in contrast to the large number of widely distributed living species (Lundblad, 1954; Jovet-Ast, 1967; Krassilov and Schuster, 1984). To date, only eight fossil species have been assigned to this family. Only gametophytes are known from the Ricciaceae fossil record. Except the Oligocene Riccia thongjaorokensis Hemanta Singh and Kishor (Hemanta Singh and Kishor, 2009) and the middle Paleocene Ricciopsis speirsae Hoffman and Stockey (Hoffman and Stockey, 1997), the other six species are from the Mesozoic (Lundblad, 1954; Sheikh and Kapgate, 1982; Anderson and Anderson, 1985; Cladera et al., 2007; Moisan et al., 2012). Ricciopsis ferganica Moisan, Voigt, Schneider and Kerp from the Middle-Late Triassic is the oldest known record.
The coal-bearing Xishanyao Formation is widely distributed in the Junggar and Turpan-Hami Basins (Sun et al., 2010; Dong, 2012). The plant macrofossils from this formation in the TurpanHami Basin have not been extensively studied compared with those from the same horizon in the Junggar Basin (Sha and Jiang, 2004; Sun et al., 2004, 2006; Miao, 2006; Nosova et al., 2011; Dong, 2012). To date, the Xishanyao Formation has yielded two fossil species of liverworts, Metzgerites barkolensis $\mathrm{Wu}(\mathrm{Wu}, 1996)$ and Pallaviciniites sandaolingensis $\mathrm{Li}$ and $\mathrm{Sun}$ ( $\mathrm{Li}$ et al., 2016a).

In this paper, we describe a new thalloid liverwort species, Ricciopsis sandaolingensis sp. nov., representing a new liverwort fossil record from the Middle Jurassic Xishanyao Formation at the Sandaoling coal mine, Xinjiang, Northwest China.

\section{MATERIAL AND METHODS}

Nine compression specimens described herein were discovered in greyish white, fine sandstone of the Xishanyao Formation at the Sandaoling open-cast coal mine, located about $90 \mathrm{~km}$ northwest of Hami, Xinjiang, Northwest China $\left(43^{\circ} 07^{\prime} \mathrm{N}, 92^{\circ} 39^{\prime} \mathrm{E}\right.$; Figure 1$)$. The Xishanyao Formation at the Sandaoling coal mine in the TurpanHami Basin conformably overlies the Lower Jurassic Sangonghe Formation and underlies the Paleocene strata (Liu, 1994). The age is proposed as early-middle Middle Jurassic based on biostratigraphic correlations (Liu, 1994; Shang et al., 1999; Deng et al., 2010). This formation mainly consists of grayish white or grayish green fine-grained sandstone and siltstone alternating with grayish to dark gray mudstone intercalated with conglomerate and coal seams or beds (Figure 2).

Some carbon material were mechanically removed from the specimens and were processed

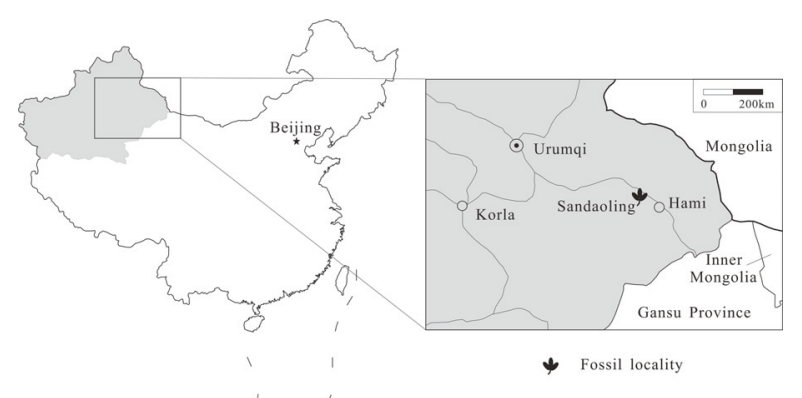

FIGURE 1. Sketch map showing the fossil locality in Turpan-Hami Basin, Xinjiang, NW China. 

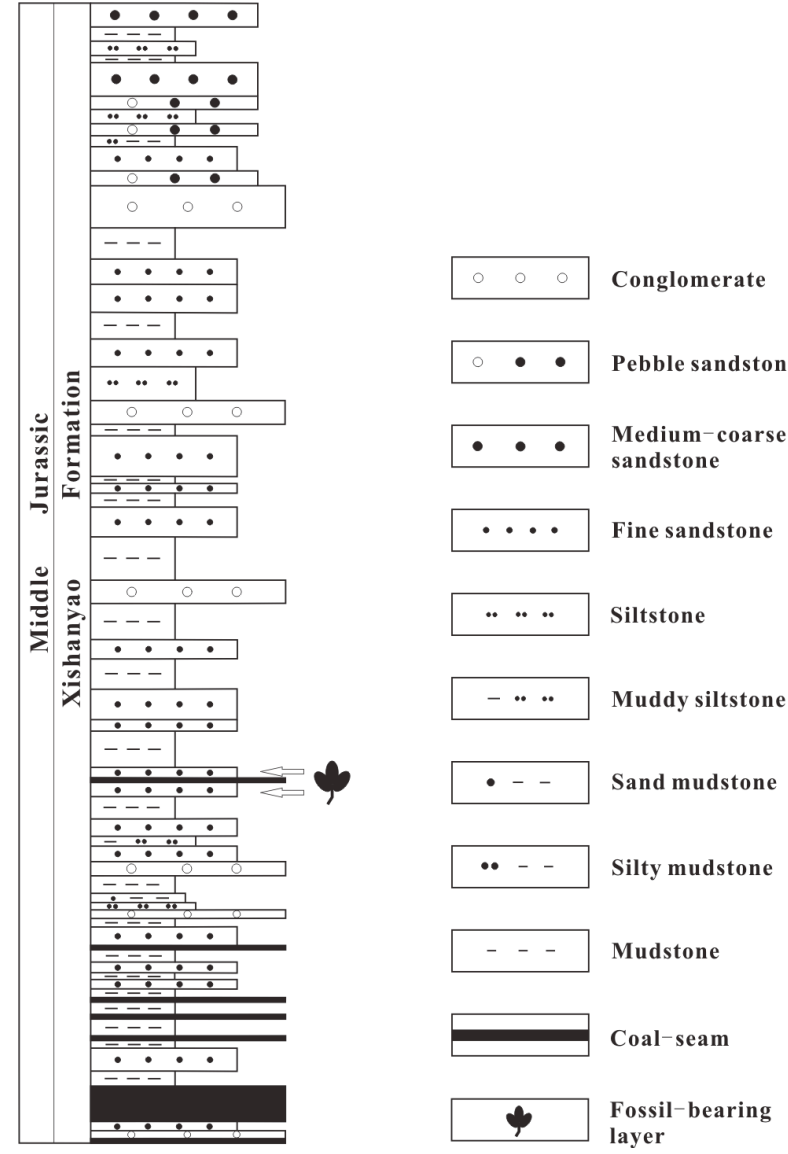

FIGURE 2. Stratigraphic section of the Middle Jurassic Xishanyao Formation in the Sandaoling open-cast coal mine, Hami, China. (Modified from figure 1 of Zhao et al., 2018).

with $10 \% \mathrm{HCl}, 50 \% \mathrm{HF}$ and $5.25 \% \mathrm{NaClO}$ solution to obtain cuticle for observing epidermal features. After staining in $0.5 \%$ safranin solution, the cuticle fragments, ventral scales and rhizoids were embedded in glycerine jelly and mounted on slides.

Photographs were taken using a Sony NEX-7 digital camera and a Leica MZ 12.5 stereomicroscope. Micrographs were taken using a Leica DM4000B light microscope. Images were processed using Photoshop CS3. All specimens are deposited in the Institute of Paleontology and Stratigraphy, Lanzhou University, Gansu Province, China. The specimens are numbered starting with the prefix LDGSW (abbreviation for the Chinese name of the Institute of Paleontology and Stratigraphy, Lanzhou University), followed by the year of collection and then a specimen number. We use the lower case letters to refer to individual thalli on the same hand specimen.

\section{SYSTEMATIC PALAEOBOTANY}

Order MARCHANTIALES Limpricht, 1877

Family RICCIACEAE Reichenbach, 1828

Genus RICCIOPSIS Lundblad, 1954

Type species. Ricciopsis florinii Lundblad, 1954

Ricciopsis sandaolingensis $\mathrm{Li}$ and Sun sp. nov.

Figures 3.1-7, 4, 5

Etymology. The specific epithet, sandaolingensis, refers to the occurrence of the species at the Sandaoling coal mine.

Holotype. Here we designate the thallus marked by the lower case letter $d$ on specimen LDGSW2013-235 as the holotype (Figure 3.1, 3.3, 3.6).

Paratypes. LDGSW-2013-208 (Figure 4.1, 4.3-5); LDGSW-2013-210; LDGSW-2013-216; LDGSW2013-217; LDGSW-2013-224; LDGSW-2013-227 (Figure 4.2); LDGSW-2013-231; LDGSW-2013232.

Type locality. Sandaoling coal mine, Hami City, Xinjiang, China.

Stratigraphy. Xishanyao Formation, Middle Jurassic.

Diagnosis. Plant thalloid. Thallus prostrate and circular. Thallus rosette-forming, branches dichotomous and growing radially from the center with at least four dichotomies. Branch bases narrow and not fused. Segments linear, with rounded apex and entire margin. Median ridge narrow and thick. Wings thin. Epidermal cells polygonal. Ventral scales semicircular, with papillae on the margin. Cells of ventral scales rounded or polygonal. Rhizoids pegged or smooth.

Description. The plants are thalloid. The thallus is prostrate, rosette and circular. The thallus size is 26-37 mm in diameter. Thalli grow in colonies (Figure $3.1,3.7$ ). A single thallus has at least five branches. Branches grow radially and symmetrically from the center (Figure 3.2, 3.4). Bases of the branches are not fused (Figure 3.7). Each branch dichotomously branching up to four times, the branching angles ranging from $34^{\circ}$ to $55^{\circ}$ (Figures $3.5,4.3,4.5)$. The base of the first segment before the first dichotomy is narrow compared with other parts of the thallus segments (Figures 3.5, 3.7, 4.5). The surface of thallus has a narrow ridge along the middle of the segment, without striae or air chambers (Figures 3.3, 3.6, 4.4).

The segments are linear with entire margins, 1.9-3.7 $\mathrm{mm}$ wide. Median ridge is prominent and narrow, $0.8 \mathrm{~mm}$ wide (Figures 3.5, 4.3, 5.1). Wings are thin (Figure 5.2). The apex of the final segment is rounded (Figure 3.5-6). Epidermal cells are polygonal (Figure 5.3-5), 20-26 $\mu \mathrm{m}$ wide. Ventral 


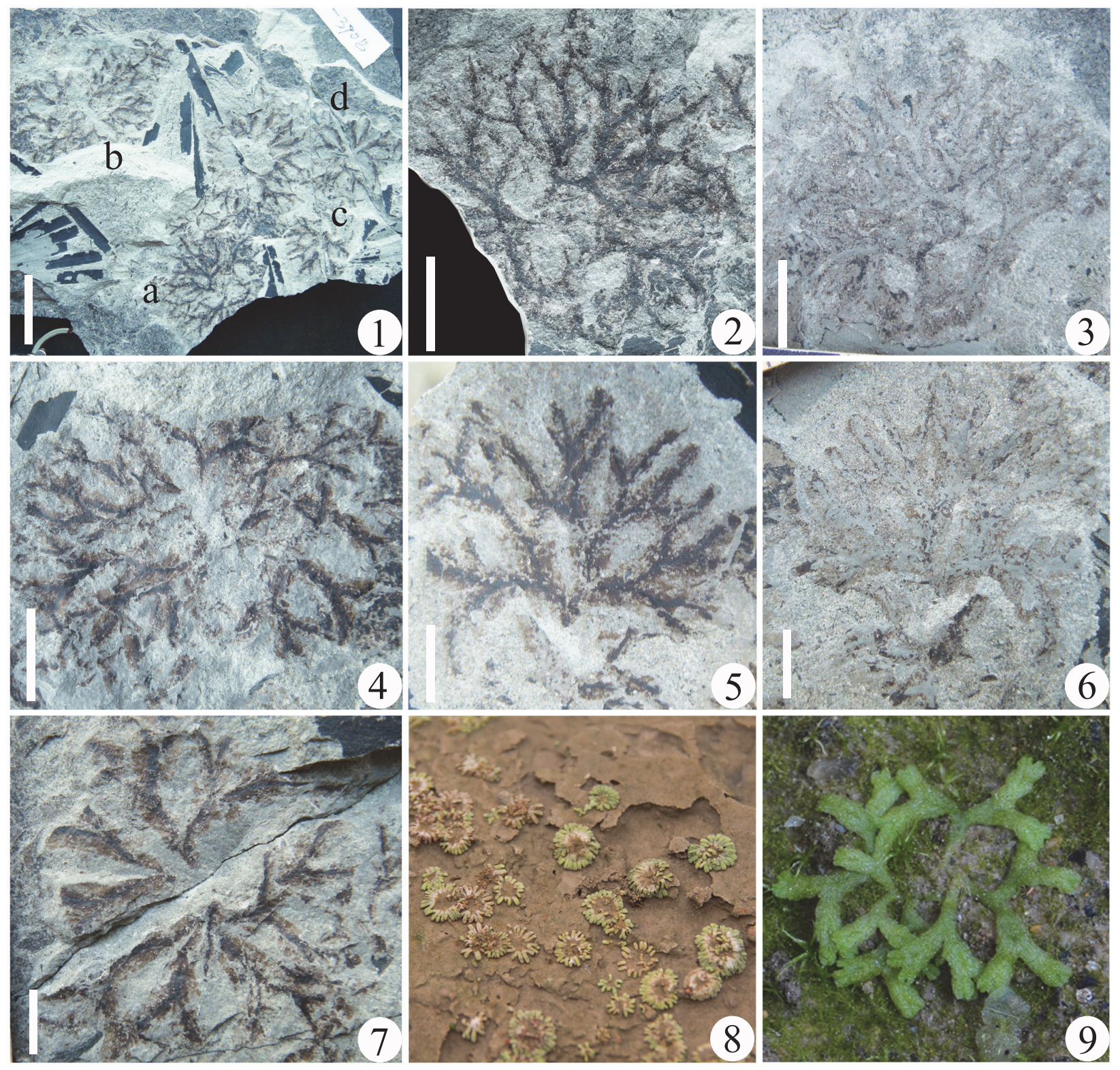

FIGURE 3. Thalli of Ricciopsis sandaolingensis sp. nov. (1-7) and extant Riccia sp. for comparison (8-9). 1, A colony of thalli, specimen LDGSW-2013-235. 2, Close-up of a in Figure 3.1 to show branch angles. 3, Counterpart of Figure 3.2 to show smooth surface of segments. 4, Close-up of b in Figure 3.1 to show branch angles. 5, Close-up of $c$ in Figure 3.1 to show branching times. 6, Counterpart of Figure 3.4 to show apex shape. 7, Close-up of $d$ in Figure 3.1 to show a single thallus and the base shape of the first segment before the first dichotomy. 8-9, Extant Riccia sp. for comparison (Photographed respectively by Jiming Liu and Binghua Chen and downloaded from the Plant Photo Bank of China). Sizes are unknown. Scale bar length: $1=2 \mathrm{~cm}, 2-4=1 \mathrm{~cm}, 5-7=0.5 \mathrm{~cm}$.

scales are semicircular, ca. $50 \mu \mathrm{m}$ in radius and with marginal papillae (Figure 5.8-9). Cells of ventral scales are rounded or polygonal (Figure 5.8-9). Rhizoids are pegged or smooth, unicellular, 13-19 $\mu \mathrm{m}$ in width and at least $0.8 \mathrm{~mm}$ in length (Figure 5.6-7).

\section{Comparison}

Assignment to Ricciopsis. The most significant feature of the present specimens is the rosetteforming thalli. In extant liverworts, only some Ricciaceae species show this feature (Gao and $\mathrm{Wu}$, 2010; Wu et al., 2013). The family Ricciaceae includes two extant genera, Riccia and Ricciocarpos, and one fossil genus Ricciopsis. The present 


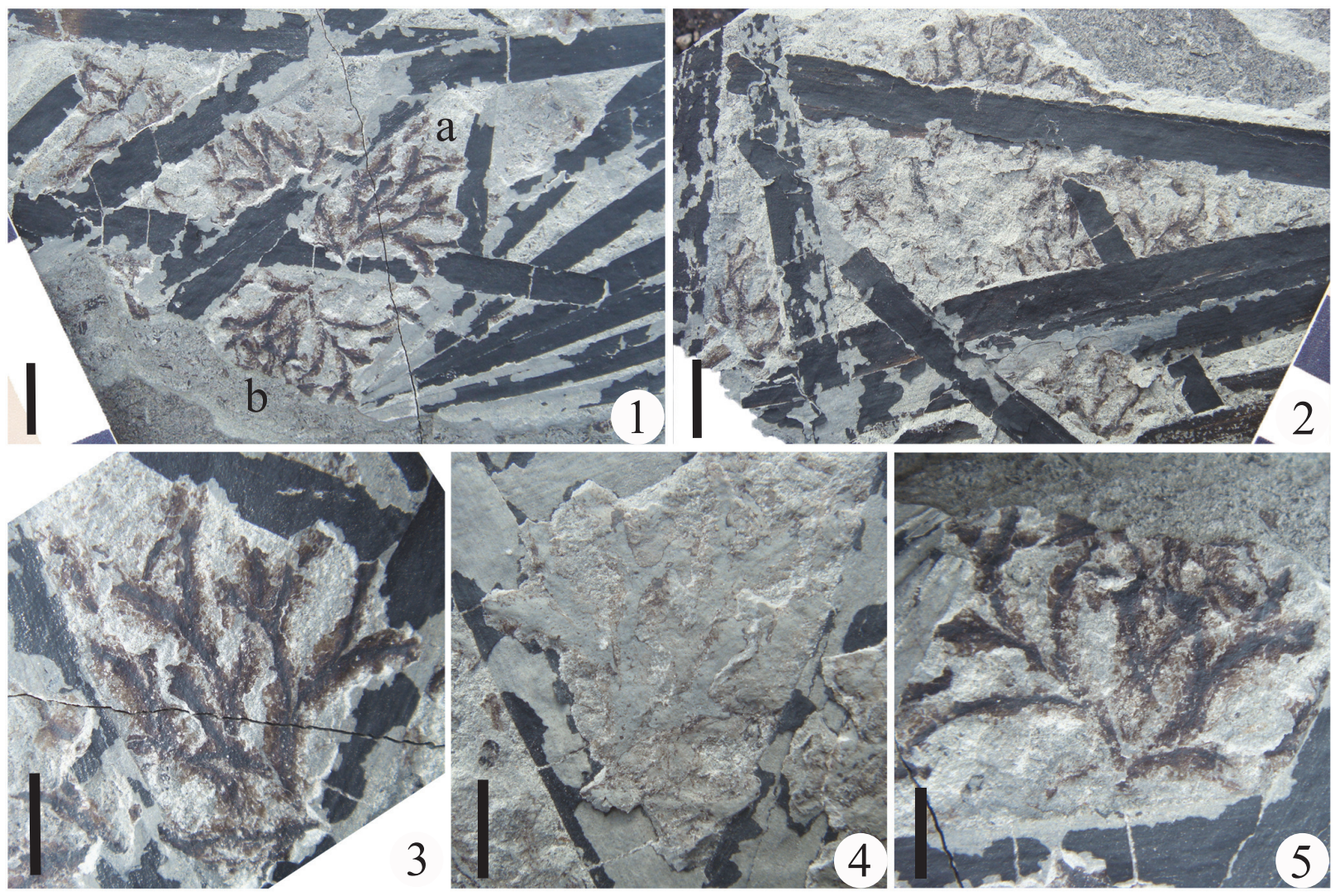

FIGURE 4. Thalli of Ricciopsis sandaolingensis sp. nov. co-occur with ginkgoalean leaves. 1, Specimen showing thalli of $R$. sandaolingensis and ginkgoalean leaves preserved on the same bedding surface, specimen LDGSW-2013-208. 2, Specimen showing thalli of $R$. sandaolingensis and ginkgoalean leaves preserved on the same bedding surface, specimen LDGSW-2013-227. 3, Close-up of a in Figure 4.1 to show segment shape. 4, Counterpart of Figure 4.3 to show smooth surface of segments. 5, Close-up of $b$ in Figure 3.1 to show segment shape. Scale bar length: 1-2 = 1 $\mathrm{cm}, 3-5=0.5 \mathrm{~cm}$.

fossil species shows many features similar to the extant Riccia species, including rosette-shaped thalli, dichotomous branching and linear segments (Figure 3.1, 3.7). However, reproductive organs are not preserved, and the present specimens are from the Middle Jurassic. We therefore assign the Sandaoling specimens to Ricciopsis, a fossil genus whose thalli demonstrate a close resemblance to those of extant Riccia (Lundblad, 1954).

Based on material from the upper coal bed (Liassic or Lower Jurassic) in Skromberga, Sweden, Lundblad (1954, p. 387) proposed the fossil genus Ricciopsis for sterile fossil thalli of Hepatics showing closer resemblance to the Ricciineae than to any other living group. She described two species and designated Ricciopsis florinii (Lundblad, 1954, p. 387-390, plate I, 1-4; plate II; figure 1A) as the type species. Although no particular characters were provided in the generic diagnosis, Lundblad (1954, p. 390) did mention that the very prominent median channels or furrows in the thallus seg- ments of the type species are very characteristic of several members of the Ricciaceae.

Comparison with fossil species of Ricciaceae. Eight known fossil species have been assigned to Ricciaceae, i.e., Riccia chitaleyii Sheikh et Kapgate, Riccia thongjaorokensis, Ricciopsis algoaensis Gianniny et Wiens, Ricciopsis ferganica, Ricciopsis florinii Lundblad, Ricciopsis grandensis Cladera et al., Ricciopsis scanica Lundblad and Ricciopsis speirsae. The main differences between these species and the present new species are thallus shape and size, number of dichotomies, segment shape, segment surface features and characters of the epidermal cells, ventral scales and rhizoids (Table 1).

The new species, Ricciopsis sandaolingensis, is similar to the type species, Ricciopsis florinii from the Early Jurassic of Skromberga (Lundblad, 1954, plate I, figures 1-4; plate II, figures $1 \mathrm{~A}$ ), in that they both have rosette-forming thalli and prominent median segment furrows. However, they differ in that in $R$. sandaolingensis the thallus size is larger, 

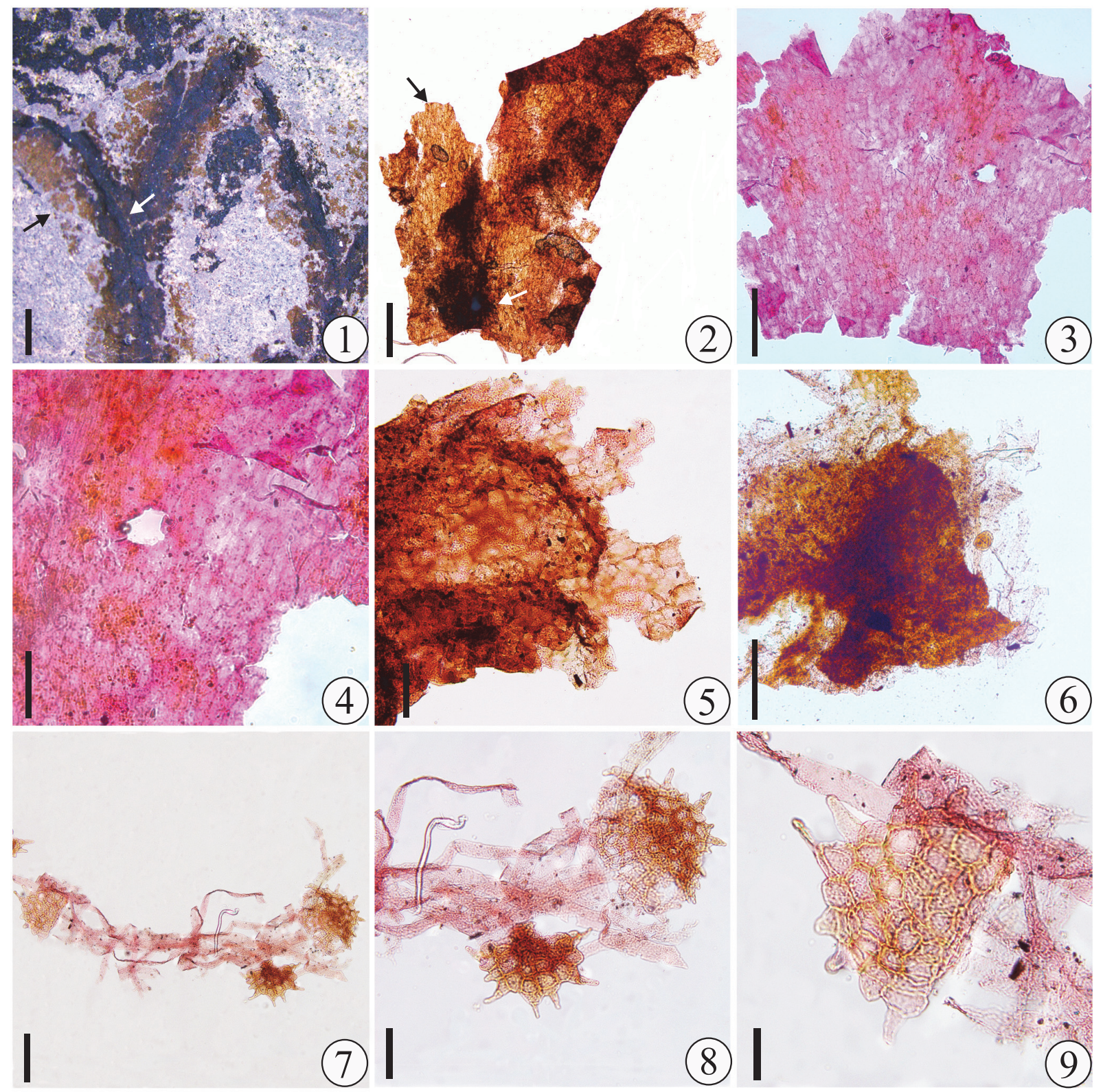

FIGURE 5. Microstructures of Ricciopsis sandaolingensis sp. nov. 1, Close of up of Figure 3.4 to show median ridge on the segment surface (indicated by white arrow) and entire margin (indicated by the black arrow). 2, Cuticle fragment showing the thick median ridge (indicated by the white arrow) and the thin wings (indicated by the black arrow). 3 and 5, Cuticle fragment showing rounded or polygonal, anticlinal epidermal cell walls. 4, Close-up of Figure 5.3 to show epidermal cell shape. 6, Rhizoids attached to cuticle fragment. 7-9, Rhizoids and ventral scales. Scale bar length: $1=1 \mathrm{~mm} ; 2-3=0.2 \mathrm{~mm} ; 4$ and $7=0.1 \mathrm{~mm} ; 5,6,8=0.05 \mathrm{~mm} ; 9=0.025 \mathrm{~mm}$.

the bases of adjacent branches are not fused, its segment are linear, epidermal cells are smaller and rhizoids are unicellular. The new species differs from Ricciopsis scanica, also from the Early Jurassic of Skromberga (Lundblad, 1954, p. 391, plate III, figures 1-5) in that $R$. scanica has smaller thallus size (10 mm vs. $26-37 \mathrm{~mm}$ ), narrower seg- ments ( $1 \mathrm{~mm}$ vs. $1.9-3.7 \mathrm{~mm}$ ), fewer branches (4 vs. 5 ), and fewer dichotomies (2 vs. 4 ).

Ricciopsis grandensis from the Early Cretaceous of Patagonia, Argentina, is another rosetteforming thalloid liverwort with dichotomous branching, prominent "midribs" on the thallus surface and segments with entire margins (Cladera et al., 2007, p. 51-53, figure $4 A$ ). However, in comparison with 





$R$. sandaolingensis, Ricciopsis grandensis has smaller thallus size (13 mm vs. $36-37 \mathrm{~mm}$ ), fewer number of dichotomies (3 vs. 4), narrower segments (1-2 mm vs. 1.9-3.7 mm) and fused bases of adjacent branches. Ricciopsis algoaensis Gianniny and Wiens from the Early Cretaceous of South Africa (Anderson and Anderson, 1985, p. 163, plate 205, figures 4-7) differs from the new species in having smaller thallus size ( $9 \mathrm{~mm}$ in diameter), more number of forking (up to six times) and thallus segments composing of midrib alone with no marginal wings and the absence of apparent ornamentation. Ricciopsis sp. (Li et al., 2016b, p. 842, figure 4) from the Early Cretaceous Huolinhe Formation of Inner Mongolia, China, also has rosetteforming thallus (Li et al., 2016b), but its asymmetrical growth pattern of the thallus is different from the new species.

Both Riccia chitaleyii from the Upper Cretaceous of Deccan Intertrappean beds of India (Sheikh and Kapgate, 1982) and Riccia thongjaorokensis from the Oligocene beds of northeastern India (Hemanta Singh and Kishor, 2009) have rosette-shaped thalli. Riccia chitaleyii has air spaces on the dorsal surface and storage parenchyma on the ventral surface of the thalli. The individual rosettes of Riccia thongjaorokensis are large (75 $\mathrm{mm}$ in diameter), and the thallus has wide longitudinal grooves on the dorsal surface. The new species differs from the two Indian species in that the air spaces and the longitudinal grooves are absent and its rosette size is smaller (26-37 $\mathrm{mm}$ in diameter).

The other two species, Ricciopsis ferganica from the Middle-Late Triassic Madygen Lagerstätte, southwestern Kyrgyzstan (Moisan et al., 2012, p. 33, plate I, figures 1-7) and Ricciopsis speirsae from the middle Paleocene Joffre Bridge locality, Alberta, Canada (Hoffman and Stockey, 1997, p. 1376-1377, figures 3-8), are not rosetteforming, and they can be easily distinguished from $R$. sandaolingensis.

Based on the unique suite of features of the present specimens (Table 1), including thallus shape and size, segment shape, segment width, number of dichotomies and smooth thallus surface, we establish a new species within the fossil genus Ricciopsis.

\section{PALEOECOLOGY}

The Xishanyao Formation in Sandaoling coal mine has yielded abundant plant fossils (Shang et al., 1999; Zhao et al., 2018). The exquisite preservation of some delicate plant material probably indicates that these fossils had undergone little or no transportation before their burial. For example, the thalloid liverwort, Pallaviciniites sandaolingensis $\mathrm{Li}$ and Sun, are preserved with complete thallus, epidermal cellular details and dense masses of fragile, unicellular rhizoids ( $\mathrm{Li}$ et al., 2016a). The conifer, Elatides sandaolingensis Z.X. Wang and B.N. Sun has leafy shoots, pollen cones and seed cones preserved together without any sorting (Wang et al., 2015). In addition, the thalli of the present new species are preserved in colonies (Figure 3.1). All these indicate that there was no or a very short distance of transportation before these plants were deposited, inferring an autochthonous or in situ preservation.

Abundant ferns and other conifers are found in the same locality. The dominance of Osmundaceae, Dicksoniaceae and long-needled Pinaceae indicates a warm and humid paleoclimate (Shang et al., 1999; Deng et al., 2010). The sporopollen fossils are attributed to the Cyathidites minor Osmundacidites - nonstriate bisaccate assemblage. The amount of Cyathidites and Deltoidospora, spores affiliated with the Dicksoniaceae, a family of ferns usually associated with warm and humid climates, is up to 36\% (Liu, 1990; Deng et al., 2010). The dominant members of the bivalves from the Xishanyao Formation, such as Ferganochonca, Sibrichonca, and Pseudocardinia, also indicate a warm and humid paleoclimate (Deng et al., 2010). Moreover, species that indicate a tropical or subtropical paleoclimate are absent. All these lines of evidence indicate that Ricciopsis sandaolingensis lived under warm and humid climatic conditions. Three types of sedimentary facies, including fluvial, lake and swamp facies, have been recognized in the Xishanyao Formation (Liu, 1990; Wu and Xu, 2004; Li et al., 2016a). Based on the sediments, e.g., grey and greyishgreen siltstones intercalated with mudstones, sandstones, conglomerate and coal seams, and the paleogeographic position of the Sandaoling open-cast coal mine, Shao et al. (2009) suggested that the fossil-bearing layer represents a lake depositional environment in the Turpan-Hami Basin. Other previous work (Deng et al., 2010; Wu and $\mathrm{Xu}, 2004)$ also suggests that there was a lake in the Sandaoling area during the Middle Jurassic, and the paleoclimate was warm and humid. Many ginkgoalean leaves and the thalli of the new species are preserved on the same surface and often times they are superimposed (Figures 3.1, 4.1-2). Many extant Ricciaceae species live on wet or damp soil close to bodies of water in the shade of 
trees (Gao and Wu, 2010; Wu et al., 2013). Based on these observations, it is conceivable that Ricciopsis sandaolingensis probably lived on wet or damp lakeshore soils in the shade of ginkgoalean trees in warm and humid climatic conditions, like many extant species of Ricciaceae do today (Gao and Wu, 2010; Wu et al., 2013).

\section{ACKNOWLEDGMENTS}

The authors thank Z. Wang, Y. Wang, Z. Shao and $B$. Wang for collecting the fossil specimens in the field, X. Wang for reprocessing the cuticle, two anonymous reviewers for their helpful remarks on a previous version of the manuscript and $\mathrm{J}$. Blanchard for proofreading the final version of the manuscript. This work is supported by the National Natural Science Foundation of China (Grant nos. 41621003, 41702013), the 111 Project (Grant No. D17013) and the Scientific Research Fund of Northwest University (Grant nos. 338020001, 338050002).

\section{REFERENCES}

Anderson, J.M. and Anderson, H.M. 1985. Palaeoflora of South Africa: Prodromus of South African Megafloras, Devonian to Lower Cretaceous. A.A. Balkema, Rotterdam.

Bippus, A.C., Stockey, R.A., Rothwell, G.W., and Tomescu, A.M.F. 2017. Extending the fossil record of Polytrichaceae: Early Cretaceous Meantoinea alophosioides gen. et sp. nov., permineralized gametophytes with gemma cups from Vancouver Island. American Journal of Botany, 104(4):584-597. https://doi.org/10.3732/ajb.1700002

Cladera, G., Fueyo, G.M.D., Seoane, L.V.D., and Archangelsky, S. 2007. Early Cretaceous riparian vegetation in Patagonia, Argentina. Revista del Museo Argentino de Ciencias Naturales, 9(1):49-58. https://doi.org/10.22179/revmacn.9.364

Crandall-Stotler, B. and Stotler, R.E. 2000. Morphology and classification of the Marchantiophyta, p. 21-70. In Goffinet, B. and Shaw, A.J. (eds.), Bryophyte Biology. Cambridge University Press, Cambridge. https://doi.org/10.1017/cbo9781139171304.003

Deng, S.H., Lu, Y.Z., Fan, R., Pan, Y.H., Cheng, X.S., Fu, G.B., Wang, Q.F., Pan, H.Z., Shen, Y.B., Wang, Y.Q., Pan, H.Z., Shen, Y.B., Wang, Y.Q., Zhang, H.C., Jia, C.K., Duan, W.Z., and Fang, L.H. 2010. The Jurassic System of Northern Xinjiang, China, p. 62-204. In Sha, J.G., Shi, X.Y., Zhou, Z.H., and Wang, Y.D. (eds.), Contributions to the $8^{\text {th }}$ International Congress on the Jurassic System. University of Science \& Technology of China Press, Hefei.

Devos, N. and Vanderpoorten, A. 2009. Range disjunctions, speciation, and morphological transformation rates in the liverwort genus Leptoscyphus. Evolution, 63:779-792. https:// doi.org/10.1111/j.1558-5646.2008.00567.x

Dong, M. 2012. Middle Jurassic plants from Shaerhu Coal Field of Xinjiang, China. Ph.D. dissertation, Jilin University, Changchun, Jilin Province, China. (In Chinese with English abstract)

Frahm, J.P. and Newton, A.E. 2005. A new contribution to the moss flora of Dominican amber. Bryologist, 108:526-536. https://doi.org/10.1639/0007-2745(2005)108[0526:ancttm]2.0.co;2

Gao, Q. and Wu, Y.H. 2010. Genera Hepaticopsida et Anthocerotopsida Sinicorum. Science Press, Beijing. (In Chinese)

Glime, J.M. 2013. Meet the Bryophytes, (no page numbers). In Glime, J.M. (ed.), Bryophyte Ecology, Physiological Ecology, Volume 1, Chapter 2-1. Ebook sponsored by Michigan Technological University and the International Association of Bryologists. Last updated 28 June 2013 and available at www.bryoecol.mtu.edu.

Heinrichs, J., Feldberg, K., Müller, P., Schafer-Verwimp, A., Konrat, M.V., Ilsemann, B., and Krings, M. 2017. Frullania pinnata spec. nov. (Frullaniaceae, Porellales), a new leafy liverwort in mid-Cretaceous Burmese amber from Myanmar. Cretaceous Research, 78:5660. https://doi.org/10.1016/j.cretres.2017.05.030

Hemanta Singh, R.K. and Kishor, R.K. 2009. Riccia thongjaorokensis - A new fossil liverwort from Oligocene Beds of the Tertiary, Northeast India. Journal Geological Society of India, 73:606-608. https://doi.org/10.1007/s12594-009-0046-4 
Hoffman, G.L. and Stockey, R.A. 1997. Morphology and paleoecology of Ricciopsis speirsae sp. nov. (Ricciaceae), a fossil liverwort from the Paleocene Joffre Bridge locality, Alberta, Canada. Canadian Journal of Botany, 75:1375-1381.

Jordan, G.J. 2006. Fossil record of bryophytes, flora of Australia, p. 58-66. In McCarthy, P.M. (ed.), Australian Biological Resources Study. CSIRO Publishing, Australia.

Jovet-Ast, S. 1967. Bryophyta, p. 20-39. In Boureau, E. (ed.), Traité de Paléobotanique, II. Bryophyta, Psilophy ta, Lycophyta. Masson et Cie, Paris.

Krassilov, V.A. and Schuster, R.M. 1984. Paleozoic and Mesozoic fossils, p. 1172-1193. In Schuster, R.M. (ed.), A New Manual of Bryology. Hattori Botanical Laboratory, Obi, Japan.

Lacey, W.S. 1969. Fossil bryophytes. Biological Reviews, 44:189-205.

Li, R.Y., Wang, X.L., Chen, J.W., Deng, S.H., Wang, Z.X., Dong, J.L., and Sun, B.N. 2016a. A new thalloid liverwort: Pallaviciniites sandaolingensis sp. nov. from the Middle Jurassic of Turpan-Hami Basin, NW China. Paläontologische Zeitschrift, 90:983-397. https://doi.org/ 10.1007/s12542-016-0299-3

Li, R.Y., Wang, X.L., Jin, P.H., Ma, F.J., Yan, D.F., Lin, Z.C., and Sun, B.N. 2016b. Fossil liverworts from the Lower Cretaceous Huolinhe Formation in Inner Mongolia, China. Acta Geologica Sinica (English Edition), 90(3):838-846. https://doi.org/10.1111/1755-6724.12727

Limpricht, K.G. 1877. Lebermoose, p. 225-352. In Cohn, F. (ed.), Kryptogamen-Flora von Schlesien, Vol. 1. J.U. Kern, Breslau.

Liu, H.F. 1994. Early-Middle Jurassic palynological assemblages of Tulufan-Hami Basin. Journal of Northwest University (Natural Science Edition), 24(6):537-539. (In Chinese with English abstract)

Liu, Z.S. 1990. Sporo-pollen assemblage from Middle Jurassic Xishanyao Formation of Shawan, Xinjiang, China. Acta Palaeontologica Sinica, 29(1):65-83.

Lundblad, B. 1954. Contributions to the geological history of the Hepaticae. Fossil Marchantiales from the Rhaetic-Liassic coalmines of Skromberga (Prov. of Scania), Sweden. Svensk Botanisk Tidskrift, 48:382-417.

Mamontov, Y.S., Ignatov, M.S., and Perkovsky, E.E. 2018. Hepatics from Rovno amber (Ukraine), 7. Frullania zerovii, sp. nov. Nova Hedwigia, 106(1-2):103-113. https://doi.org/ 10.1127/nova_hedwigia/2017/0446

Miao, Y.Y. 2006. Ginkgoales and Czekanowskiales from the Middle Jurassic in western Junggar Basin of Xinjiang, China. Ph.D. dissertation, Jilin University, Changchun, Jilin Province, China. (In Chinese with English abstract)

Moisan, P., Voigt, S., Schneider, J.W., and Kerp, H. 2012. New fossil bryophytes from the Triassic Madygen Lagerstätte (SW Kyrgyzstan). Review of Palaeobotany and Palynology, 187:29-37. https://doi.org/10.1016/j.revpalbo.2012.08.009

Nosova, N., Zhang, J.W., and Li, C.S. 2011. Revision of Ginkgoites obrutschewii (Seward) Seward (Ginkgoales) and the new material from the Jurassic of Northwestern China. Review of Palaeobotany and Palynology, 166(3):286-294. https://doi.org/10.1016/ j.revpalbo.2011.06.002

Reichenbach, H.G.L. 1828. Botanik für Damen, Künstler und Freunde der Pflanzenwelt überhaupt, enthaltend eine Darstellung des Pflanzenreichs in seiner Metamorphose, eine Anleitung zum Studium der Wissenschaft und zum Anlegen von Herbarien. Polskie Towarzystwo Botaniczne, Leipzig.

Savoretti, A., Bippus, A.C., Stockey, R.A., Rothwell, G.W., and Tomescu, A.M.F. 2018. Grimmiaceae in the Early Cretaceous: Tricarinella crassiphylla gen. et sp. nov. and the value of anatomically preserved bryophytes. Annals of Botany, 121(7):1275-1286. https://doi.org/ 10.1093/aob/mcy015

Sha, J.G. and Jiang, B.Y. 2004. Characteristics of the Lower and Middle Jurassic stages in Zhungeer Basin, northwestern China. Journal of Heilongjiang Institute of Science and Technology, 14(3):137-139. (In Chinese with English abstract)

Shang, P., Fu, G.B., Hou, Q.Z., and Deng, S.H. 1999. Middle Jurassic fossil plants from TurpanHami Basin, Xinjiang, Northwest China. Geoscience, 13(4):403-407. (In Chinese with English abstract)

Shao, L.Y., Gao, D., Luo, Z., and Zhang, P.F. 2009. Sequence stratigraphy and palaeogeography of the Lower and Middle Jurassic coal measures in Turpan-Hami Basin. Journal of Palaeogeography, 11(2):215-224.

Sheikh, M.T. and Kapgate, D.K. 1982. First petrified fossil Riccia L. from Indian beds. Current Science, 51:241-242. 
Shelton, G.W.K., Stockey, R.A., Rothwell, G.W., and Tomescu, A.M.F. 2015. Exploring the fossil history of pleurocarpous mosses: Tricostaceae fam. nov. from the Cretaceous of Vancouver Island, Canada. American Journal of Botany, 102(11):1883-1900. https://doi.org/10.3732/ ajb. 1500360

Shelton, G.W.K., Stockey, R.A., Rothwell, G.W., and Tomescu, A.M.F. 2016. Krassiloviella limbelloides gen. et sp. nov.: Additional diversity in the hypnanaean moss family Tricostaceae (Valanginian, Vancouver Island, British Columbia). International Journal of Plant Sciences, 177(9):792-808. https://doi.org/10.1086/688707

Söderström, L., Hagborg, A., von Konrat, M., Bartholomew-Began, S., Bell, D., Briscoe, L., Brown, E., Cargill, D.C., Costa, D.P., Crandall-Stotler, B.J., Cooper, E.D., Dauphin, G., Engel, J.J., Feldberg, K., Glenny, D., Gradstein, S.R., He, X., Heinrichs, J., Hentschel, J., IlkiuBorges, A.L., Katagiri, T., Konstantinova, N.A., Larraín, J., Long, D.G., Nebel, M., Pócs, T., Felisa Puche, F., Reiner-Drehwald, E., Renner, M.A.M., Sass-Gyarmati, A., SchäferVerwimp, A., Moragues, J.G.S., Stotler, R.E., Sukkharak, P., Thiers, B.M., Uribe, J., Váňa, J., Villarreal, J.C., Wigginton, M., Zhang, L., and Zhu, R.L. 2016. World checklist of hornworts and liverworts. PhytoKeys, 59:1-828. https://doi.org/10.3897/phytokeys.59.6261

Sun, G., Miao, Y.Y., and Chen, Y.J. 2006. A new species of Sphenobaiera from Middle Jurassic of Junggar Basin, Xinjiang, China. Journal of Jilin University (Earth Science Edition), 36(5):717-722. (In Chinese with English abstract)

Sun, G., Miao, Y.Y., Mosbrugger, V., and Ashraf, A.R. 2010. The Upper Triassic to Middle Jurassic strata and floras of the Junggar Basin, Xinjiang, Northwest China. Palaeobiodiversity and Palaeoenvironments, 90:203-214. https://doi.org/10.1007/s12549010-0039-8

Sun, G., Miao Y. Y., Sun Y.W., Li, J., and Mosbrugger, V. 2004. Middle Jurassic plants from Baiyan River area of Emin, northwestern Junggar Basin, Xinjiang, p. 35-40. In Sun, G., Mosbrugger, V., Ashraf, A.R., and Sun, Y.W. (eds.), Proceedings Sino-German Cooperation Symposium on Paleontology, Geological Evolution and Environmental Changes of Xinjiang, China. Jilin University Press, Changchun.

Tomescu, A.M.F. 2016. The Early Cretaceous Apple Bay flora of Vancouver Island: a hotspot of fossil bryophyte diversity. Botany, 94:683-695. https://doi.org/10.1139/cjb-2016-0054

Tomescu, A.M.F., Bomfleur, B., Bippus, A.C., and Savoretti, A. 2018. Why are bryophytes so rare in the fossil record? A spotlight on taphonomy and fossil preservation, p. 375-416. In Mcloughlin, S., Bomfleur, B., and Drinnan, A. (eds.), Transformative Paleobotany. Elsevier. https://doi.org/10.1016/B978-0-12-813012-4.00016-4

Wang, Z.X., Wang, X.L., Chen, J.W., Deng, P., Wang, T.Z., Li, R.Y., and Sun, B.N. 2015. Elatides sandaolingensis $\mathrm{n}$. $\mathrm{sp}$. (Cupressaceae sensu lato) - A new fossil conifer with cones from the Middle Jurassic of Xinjiang, northwestern China. Palaeoworld, 25(2):239-250. https://doi.org/ 10.1016/j.palwor.2015.11.010

Wu, B.L. and Xu, G.Z. 2004. Evolution feature of palaeoclimate and significance of sequence stratigraphy in Suixigou Group in the southwest edge of Turpan-Hami Basin. Journal of East China Institute of Technology, 27(2):135-140.

Wu, P.C., Jia, Y., and Zhang, L. 2013. Higher Plants of China, Volume 1, p. 269. In Fu, L.G., Chen, T.Q., Lang, K.Y., Hong, T., Lin, Q., and Li, Y. (eds.), Higher Plants of China. Qingdao Publishing House, Qingdao. (In Chinese)

$\mathrm{Wu}$, X.W. 1996. On four species of hepatics from Jurassic of Junggar Basin and Barkol District in Xinjiang, China. Acta Palaeontologica Sinica, 35(1):60-71. (In Chinese with English abstract)

Zhao, Y., Deng, S.H., Shang, P., Leng, Q., Lu, Y.Z., Fu, G.B., and Ma, X.Y. 2018. Two new species of Nilssoniopteris (Bennettitales) from the Middle Jurassic of Sandaoling, TurpanHami Basin, Xinjiang, NW China. Journal of Paleontology, 92(4):525-545. 